\title{
Growth inhibition induced by antiprogestins RU-38486, ORG-31710, and CDB-2914 in ovarian cancer cells involves inhibition of cyclin dependent kinase 2
}

\author{
Alicia A. Goyeneche · Erin E. Seidel • Carlos M. Telleria
}

Received: 8 February 2011 / Accepted: 2 March 2011 /Published online: 22 March 2011

(C) The Author(s) 2011. This article is published with open access at Springerlink.com

\begin{abstract}
Summary Antiprogestins have been largely utilized in reproductive medicine, yet their repositioning for oncologic use is rapidly emerging. In this study we investigated the molecular mediators of the anti-ovarian cancer activity of the structurally related antiprogestins RU-38486, ORG31710 and CDB-2914. We studied the responses of wt $\mathrm{p} 53$ OV2008 and p53 null SK-OV-3 cells to varying doses of RU-38486, ORG-31710 and CDB-2914. The steroids inhibited the growth of both cell lines with a potency of RU-38486 > ORG-31710 > CDB-2914, and were cytostatic at lower doses but lethal at higher concentrations. Antiprogestin-induced lethality associated with morphological features of apoptosis, hypodiploid DNA content, DNA fragmentation, and cleavage of executer caspase substrate PARP. Cell death ensued despite RU-38486 caused transient up-regulation of anti-apoptotic Bcl-2, ORG-31710 induced transient up-regulation of inhibitor of apoptosis XIAP, and CDB-2914 up-regulated both $\mathrm{XIAP}$ and Bcl-2. The antiprogestins induced accumulation of Cdk inhibitors $\mathrm{p} 21^{\text {cip } 1}$ and $\mathrm{p} 27^{\mathrm{kip} 1}$ and increased association of $\mathrm{p} 21^{\text {cip } 1}$ and $\mathrm{p} 27^{\mathrm{kip} 1}$ with Cdk-2. They also promoted nuclear localization of $\mathrm{p} 21^{\mathrm{cip} 1}$ and $\mathrm{p} 27^{\mathrm{kip} 1}$, reduced the nuclear abundances of Cdk-2 and cyclin E, and blocked the activity of Cdk-2 in both nucleus and cytoplasm. The cytotoxic potency of the antiprogestins correlated with the magnitude of the inhibition of Cdk-2 activity, ranging from G1 cell cycle arrest towards cell
\end{abstract}

Electronic supplementary material The online version of this article (doi:10.1007/s10637-011-9655-z) contains supplementary material, which is available to authorized users.

A. A. Goyeneche $\cdot$ E. E. Seidel $\cdot$ C. M. Telleria $(\triangle)$

Division of Basic Biomedical Sciences,

Sanford School of Medicine of The University of South Dakota, Vermillion, SD, USA

e-mail: carlos.telleria@usd.edu death. Our results suggest that, as a consequence of their cytostatic and lethal effects, antiprogestin steroids of wellknown contraceptive properties emerge as attractive new agents to be repositioned for ovarian cancer therapeutics.

Keywords Cyclin dependent kinase $2 \cdot \mathrm{p} 21^{\mathrm{cip} 1} \cdot \mathrm{p} 27^{\mathrm{kip} 1}$. Antiprogestins · Ovarian cancer

\section{Introduction}

The first antiprogestin synthesized was RU-38486 (a.k.a. "RU-486"), now named mifepristone [1]. RU-38486 has been mainly used as blocker of progesterone receptors in the uterus, where it increases the sensitivity to myometrial contractions induced by prostaglandin analogues, leading to early termination of pregnancy [2]. Yet RU-38486 is useful for other reproductive indications, such as oral contraception, menstrual cycle regulation and emergency contraception [3]. More recently, RU-38486 emerged to treat endocrine-related diseases such as uterine leiomyoma and endometriosis [4].

The potential use of RU-38486 in oncology is promising. In non-reproductive tissues, RU-38486 inhibited the growth of gastric cancer cell lines [5] and of meningioma cells [6]. In reproductive tissues, RU-38486 blocked proliferation and killed benign and malignant endometrial cancer cells [7]. In prostate cancer, RU-38486 blocked growth of androgensensitive and androgen-insensitive LNCaP cells in vivo and in vitro [8]. In breast cancer, RU-38486 inhibited the growth of T-47D cells [9], and in MCF-7 cells it had an additive lethal effect when combined with antiestrogen tamoxifen [10]. In MCF-7 cells, RU-38486 had a synergistic lethal interaction with the Chk1 inhibitor 7-hydroxystaurosporine (UCN-01) [11] or with 4-hydroxytamoxifen [12]. Also, RU- 
38486 blocked the growth of MCF-7 sublines resistant to 4hydroxytamoxifen [13] and was lethal to progesterone receptor- and estrogen receptor-negative MDA-MB-231 cells [14]. In $p 53 / B R C A 1$-deficient mice, RU-38486 prevented the formation of breast tumors [15]. RU-38486 also inhibited the growth of cervical adenocarcinoma cells in vitro and in vivo [16].

The action of antiprogestins in ovarian cancer has received limited attention. First in 1996 it was revealed that RU-38486 arrested OVCAR-3 and A2780 cells at the G1 phase of the cell cycle [17]. More recently we demonstrated the efficacy of RU-38486 as a single agent in an in vivo preclinical setting and found that its growth inhibitory effect was associated with inhibition of DNA synthesis, G1 cell cycle arrest, and down-regulation of transcription factor E2F1 needed for S phase progression [18]. We also demonstrated that RU-38486 inhibits the growth of ovarian cancer cells regardless of p53 genetic makeup and platinum sensitivity [19]. Finally, we have shown that cytostatic concentrations of RU-38486 added after courses of lethal platinum-based chemotherapy prevent repopulation of remnant cancer cells escaping and surviving the insult of the platinating agent [20].

ORG-31710 and CDB-2914 are two members of a family of selective progesterone receptor modulators with a similar structure to RU-38486, as they all contain a dimethylaminophenyl substitution at the $11 \beta$-position that confers antiprogestin activity [2, 4, 21] (Fig. 1). ORG31710 and CDB-2914, however, were designed aiming to decrease the antagonistic effect of RU-38486 on the glucocorticoid receptor by substitutions made at the $17 \alpha$ side chain [4]. Limited information is available regarding the growth inhibition and oncologic value of these two antiprogestins. Studies in rats show that ORG-31710 and CDB-2914 were effective in reducing the growth of established DMBA-induced breast tumors by increasing apoptosis and blocking cell proliferation [22, 23]. In cultured human uterine leiomyoma cells, CDB-2914 inhibited cell proliferation down-regulating PCNA expression, and inducing apoptosis up-regulating PARP expression and reducing Bcl-2 abundance [24]. Further a recent randomized controlled clinical trial reported that CDB-2914 significantly reduced leiomyoma growth [25]. ORG-31710, on the other hand, increased apoptosis in human periovulatory granulosa cells [26].

Based on our previous findings on the in vitro and in vivo growth inhibitory effect of RU-38486 in ovarian cancer cells, the goal of this study was to investigate the molecular mediators of the anti-ovarian cancer activity of RU-38486 and of the two structurally related antiprogestins, ORG-31710 and CDB-2914 (Ulipristal). We report that RU-38486, ORG-31710 and CDB-2914 all are cytostatic at lower concentrations, up-regulating and promoting nuclear localization of the cyclin dependent kinase $(\mathrm{Cdk})$ inhibitors $\mathrm{p} 27^{\mathrm{kip} 1}$ and $\mathrm{p} 21^{\mathrm{cip} 1}$, reducing nuclear abundances of Cdk-2 and cyclin E, and reducing the activity of Cdk-2. At higher concentrations the three antiprogestins blunted the activity of Cdk-2 leading to the death of the ovarian cancer cells, which was associated with morphological features of apoptosis, hypodiploid DNA content, fragmentation of the DNA, and cleavage of the executer caspase substrate PARP.

\section{Materials and methods}

Cell culture and drugs

The human ovarian carcinoma cell line OV2008 was obtained in 2003 from Dr. Howell (University of California, San Diego) and was maintained in RPMI 1640 (Mediatech, Herndon, VA) supplemented with $5 \%$ heat inactivated fetal bovine serum (Atlanta Biologicals, Lawrencenville, GA), 10 mM HEPES (Mediatech), 4 mM L-glutamine (Mediatech), $1 \mathrm{mM}$ sodium pyruvate (Mediatech), $1 \mathrm{x}$ non-essential amino acids (Mediatech), $100 \mathrm{IU}$ penicillin (Mediatech), and $100 \mu \mathrm{g} / \mathrm{ml}$ streptomycin (Mediatech). SK-OV-3 ovarian cancer cells were obtained in 2003 at passage 23 from the American Tissue Culture Collection (Manassas, VA) and were routinely maintained in RPMI 1640 (Mediatech) supplemented with 5\% fetal bovine serum (Atlanta Biologicals), $10 \mathrm{mM}$ HEPES (Mediatech),
Mifepristone (RU-38486)

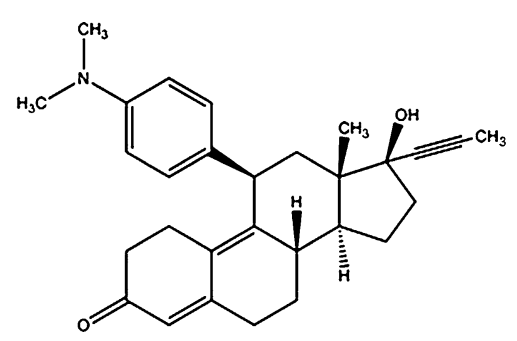

Ulipristal (CDB-2914)

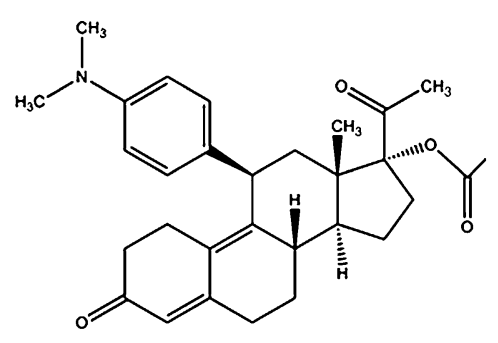

ORG-31710

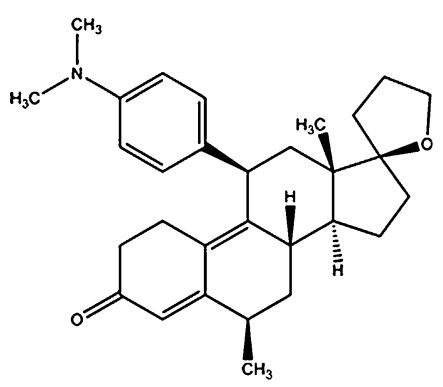

Fig. 1 Chemical structure of antiprogestins 
$4 \mathrm{mM}$ L-glutamine (Mediatech), $0.45 \% \mathrm{D}(+)$ glucose (Sigma Chemical Company, St. Louis, MO), $1 \mathrm{mM}$ sodium pyruvate (Mediatech), $1 \mathrm{x}$ non-essential amino acids (Mediatech), 100 IU penicillin (Mediatech), $100 \mu \mathrm{g} / \mathrm{ml}$ streptomycin (Mediatech), and $0.01 \mathrm{mg} / \mathrm{ml}$ human insulin (Roche, Indianapolis, IN). Both cell lines were cultured at $37^{\circ} \mathrm{C}$ in a humidified atmosphere in the presence of $5 \% \mathrm{CO}_{2}$. Treatment of the cells with RU-38486 (Sigma), ORG-31710 (generously provided by N.V. Organon, Oss, The Netherlands), or CDB-2914 (kindly provided by HRA Pharma, Paris, France) were done from $20 \mathrm{mM}$ stock solutions in DMSO; the maximal concentration of DMSO in medium was $0.2 \%(\mathrm{v} / \mathrm{v})$.

Cell proliferation and viability

Triplicate cultures were trypsinized, pelleted by centrifugation at $500 \mathrm{~g}$ for $5 \mathrm{~min}$, and washed with PBS. The cells were resuspended in ViaCount reagent (Guava Technologies, Hayward, CA) and studied using the Guava ViaCount application in the Guava EasyCyte Mini microcapillary cytometer (Guava Technologies) as we previously reported [20]. When indicated, the proliferation IC50 values were determined using software designed to study drug interaction that calculates the median effective dose, Dm, which is analogous to the IC50 (Calcusyn, Biosoft, Cambridge, UK).

\section{Cell cycle analysis}

After treatment, cells were trypsinized, pelleted by centrifugation at $500 \mathrm{~g}$ for $5 \mathrm{~min}$, washed with PBS, and fixed with $4 \%$ paraformaldehyde. Cells were once again washed with PBS and pelleted by centrifugation at $500 \mathrm{~g}$ for $5 \mathrm{~min}$. Then approximately 100,000-200,000 cells were resuspended in $200 \mu \mathrm{l}$ of cell cycle buffer [3.8 mM sodium citrate (Sigma), $7 \mathrm{U} / \mathrm{ml}$ RNase A (Sigma), 0.1\% (v/v) Triton X-100 (Sigma), and $0.05 \mathrm{mg} / \mathrm{ml}$ propidium iodide (Sigma)] at a concentration of $500-1000 \mathrm{cells} / \mu \mathrm{l}$. Cells were analyzed for the capacity of their DNA to bind propidium iodide utilizing the Guava EasyCyte Mini microcapillary cytometer and the cell cycle application of the CytoSoft 4.1 software (Guava Technologies).

\section{Immunoblot analysis}

Cells were scraped, pelleted, washed twice with PBS, and lysed by the addition of two volumes of NP-40 lysis buffer containing $50 \mathrm{mM}$ Tris- $\mathrm{HCl}$ ( $\mathrm{pH} 7.5$ ), $150 \mathrm{mM} \mathrm{NaCl}, 0.5 \%$ NP-40 (Sigma), $50 \mathrm{mM}$ sodium fluoride (Sigma), $1 \mathrm{mM}$ PMSF (Sigma), $2 \mu \mathrm{g} / \mathrm{ml}$ pepstatin (Sigma), $2 \mu \mathrm{g} / \mathrm{ml}$ leupeptin (Sigma), $2 \mu \mathrm{g} / \mathrm{ml}$ aprotinin (Sigma), and $1 \mathrm{mM}$ orthovanadate (Sigma). Lysates were centrifuged at $16,000 \mathrm{~g}$ for $15 \mathrm{~min}$ at $4^{\circ} \mathrm{C}$, and the supernatant was considered the whole cell extract, which was assayed for protein content using the bicinchoninic acid method (BCA; Pierce, Rockford, IL). The whole cell extracts were appropriately diluted in $3 \mathrm{x}$ concentrated electrophoresis sample buffer, boiled for $10 \mathrm{~min}$, and stored at $-80^{\circ} \mathrm{C}$ until electrophoresed. Equivalent amounts of proteins $(50 \mu \mathrm{g})$ per point were loaded in $12 \%(\mathrm{w} / \mathrm{v})$ acrylamide gels, subjected to SDSPAGE and transferred to PVDF membranes. The blots were blocked in $5 \%(\mathrm{v} / \mathrm{v})$ non-fat milk in TBS containing $0.1 \%(\mathrm{v} / \mathrm{v})$ Tween $20(\mathrm{~T})$. Blots were probed overnight with the appropriate dilution of each of the primary antibodies. The membranes were washed $3 \times 5 \mathrm{~min}$ in TBS-T and incubated with 1: 10,000 dilution of peroxidaseconjugate secondary antibody (\#111-035-003; Jackson ImmunoResearch Laboratories, West Grove, PA) for $30 \mathrm{~min}$ at room temperature. The blots were again washed, developed by chemiluminescence, and exposed to radiographic film. Blots were stripped and reprobed with an antibody directed against the ubiquitous proteins glyceraldehyde-3-phosphate dehydrogenase (GAPDH), or $\beta$-actin, to control for protein loading. Primary antibodies for the following proteins were used at the indicated dilutions. Cyclin E (clone HE12; $0.5 \mu \mathrm{g} / \mathrm{ml}$ ), and p21 $1^{\text {cip } 1}$ (clone $6 \mathrm{~B} 6 ; 2 \mu \mathrm{g} / \mathrm{ml}$ ) were from BD Pharmigen (San Diego, CA); p2 $7^{\text {kip } 1}$ (clone 57; 1: 2,000) was from BD Transduction Laboratories (San Diego, CA); XIAP (\#2042; 1:500), poly (ADP-ribose) polymerase (PARP; \#9592; 1:1,000) and caspase-3 (\#9662; 1:1,000) were from Cell Signaling Technology (Danvers, MA); Cdk-2 (M2; 1:1,000) and Bcl-2 (100; 1:1000) were from Santa Cruz Biotechnology (Santa Cruz, CA); GAPDH (ab9485; $1: 10,000)$ was from Abcam Inc. (Cambridge, MA); $\beta$-actin (clone AC-15; 1:20,000) was from Sigma.

\section{Cdk-2 immunoprecipitation and histone H1 kinase assay}

An aliquot (100 $\mu \mathrm{g}$ of protein) from each NP-40 cell lysate was incubated overnight at $4^{\circ} \mathrm{C}$ with constant rotation in $1 \mathrm{ml}$ of NP-40 lysis buffer containing $1 \mu \mathrm{g}$ polyclonal rabbit antibody to Cdk-2 (M2; Santa Cruz Biotechnology). Immunocomplexes associated with Cdk-2 were collected after incubation for $2 \mathrm{~h}$ with protein A/G PLUS-Agarose beads (Santa Cruz Biotechnology). The immune-complexes were washed twice with kinase buffer [50 $\mathrm{mM}$ HEPES (pH 7.2), $10 \mathrm{mM} \mathrm{MgCl}_{2}, 1 \mathrm{mM}$ DTT, $10 \mathrm{mM} \beta-$ glycerophosphate, and $1 \mathrm{mM}$ sodium fluoride]. Subsequently, the beads were resuspended in $30 \mu \mathrm{l}$ of kinase buffer containing $2 \mu \mathrm{g}$ of histone H1 (Upstate Cell Signaling Solutions, Lake Placid, NY), $5 \mu \mathrm{M}$ ATP (Upstate), and $5 \mu \mathrm{Ci}$ of $\left[\gamma^{32} \mathrm{P}\right]$ ATP (MP Biomedicals, Irvine, CA). The reaction mixtures were incubated at $30^{\circ} \mathrm{C}$ for $30 \mathrm{~min}$, the reaction was terminated with $30 \mu \mathrm{l}$ of $2 \mathrm{x}$ electrophoresis sample buffer, boiled, and separated on $12 \%$ SDS/polyacrylamide gels. Gels were stained with 
Coomassie Blue (Sigma) to visualize the histone H1 bands, dried, and autoradiographed.

\section{Subcellular fractionation}

Upon treatment with vehicle or antiprogestins, cells were washed in PBS, scrapped, pelleted, and resuspended in low salt lysis buffer [10 mM HEPES (pH 7.9), $10 \mathrm{mM} \mathrm{KCl}$, $1.5 \mathrm{mM} \mathrm{MgCl}_{2}, 1 \mathrm{mM}$ DTT, $1 \mathrm{mM}$ PMSF, $1 \mathrm{mM}$ sodium orthovanadate, $2 \mu \mathrm{g} / \mathrm{ml}$ aprotinin, $2 \mu \mathrm{g} / \mathrm{ml}$ leupeptin, and $2 \mu \mathrm{g} / \mathrm{ml}$ pepstatin], incubated on ice for $15 \mathrm{~min}$ and homogenized with a hand pestle. The lysates where then centrifuged for $10 \mathrm{~min}$ at $800 \mathrm{x} \mathrm{g}$ at $4^{\circ} \mathrm{C}$. The pellet represents the nuclear fraction. The supernatant was further centrifuged for $10 \mathrm{~min}$ at $16,000 \mathrm{xg}$ at $4^{\circ} \mathrm{C}$ to remove any contaminant nuclei. The new supernatant was considered the cytosolic fraction. The crude nuclear fraction was washed twice with low salt lysis buffer, pelleted down for $5 \mathrm{~min}$ at $800 \times \mathrm{g}$, resuspended in NP-40 lysis buffer (described above), and rocked for $1 \mathrm{~h}$ at $4{ }^{\circ} \mathrm{C}$. The suspension was centrifuged at $16,000 \times \mathrm{g}$ for $20 \mathrm{~min}$ to remove debris, and the supernatant was considered the nuclear fraction. The protein concentrations of both factions were determined as described above. Fifty $\mu \mathrm{g}$ of each of the protein fractions were subjected to SDS-PAGE, transferred to PVDF membranes, and immunoblotted with antibodies against $\mathrm{p} 27^{\mathrm{kip} 1}, \mathrm{p} 21^{\mathrm{cip} 1}, \mathrm{Cdk}-2$, cyclin E, and GAPDH or $\beta$-actin for loading control.

4', 6-Diamidino-2-phenylindole dihydochloride (DAPI) staining and phase contrast microscopy

OV2008 or SK-OV-3 cells cultured on 6-well plates were exposed to either vehicle (DMSO), or 20 or $40 \mu \mathrm{M}$ antiprogestins for $96 \mathrm{~h}$. After treatment, detached cells were collected, centrifuged at $500 \mathrm{~g}$ for $5 \mathrm{~min}$, fixed and resuspended in $100 \%$ methanol, adhered to a microscope slide, and stained for $10 \mathrm{~min}$ with DAPI (Molecular Probes, Eugene, OR). Nuclear morphology was observed and photographed using a Zeiss Axiovert M200 inverted fluorescence microscope (Carl Zeiss, Thornwood, NY). Cells that remained adherent to the original chamber slide were also fixed in $100 \%$ methanol, stained with DAPI and photographed. All cell preparations were simultaneously photographed using a phase contrast objective.

\section{DNA fragmentation}

Floating and adherent cells were pelleted and digested overnight at $50^{\circ} \mathrm{C}$ in a buffer composed of $100 \mathrm{mM} \mathrm{NaCl}$, $10 \mathrm{mM}$ Tris $\mathrm{HCl}$ (pH 8.0), $25 \mathrm{mM}$ EDTA (pH 8.0), 0.5\% SDS and $0.1 \mathrm{mg} / \mathrm{ml}$ proteinase $\mathrm{K}$ (Life Technologies, Rockville, MD). The genomic DNA was extracted from the digested cells with phenol/chloroform/isoamyl alcohol $(25: 24: 1, \mathrm{v} / \mathrm{v} / \mathrm{v})$, precipitated, and digested for $60 \mathrm{~min}$ at $37^{\circ} \mathrm{C}$ with $1 \mu \mathrm{g} / \mathrm{ml}$ ribonuclease (deoxyribonucleasefree; Roche). After extraction and precipitation, an equal amount of DNA for each sample $(2 \mu \mathrm{g})$ was separated by electrophoresis on a $2.5 \%$ agarose gel, impregnated with SYBR Gold nucleic acid gel stain (Molecular Probes), examined using an ultraviolet transilluminator, and photographed with the Amersham Typhoon Fluorescence imaging system (Amersham Biosciences Corp., Piscataway, NJ). A 100 bp DNA ladder (Promega, Madison, WI) was utilized for determining the size of the fragments of DNA.

\section{Results}

Antiprogestins inhibit, in a dose-related manner, the growth of p53 wild type and p53 mutant ovarian cancer cells, eliciting concentration dependent cytostatic and lethal effects

To explore whether RU-38486, ORG-31710 or CDB-2914 can inhibit the growth of ovarian cancer cells of different genetic backgrounds, we studied the response to the antiprogestins in OV2008 cells that express wild type p53 [27], and SK-OV-3 cells that carry a deletion of a single nucleotide as a consequence of which no p53 mRNA transcripts are expressed [28]. The two cell lines were exposed to vehicle or increasing concentrations of the antiprogestins for $72 \mathrm{~h}$. At the end of the experiment, the cells were evaluated and analyzed by microcapillary cytometry for cell number, cell viability, and cell cycle distribution. Results shown in Fig. 2a and d illustrate that both cell lines were growth inhibited by the three antiprogestins in a dose-related manner. In OV2008 cells, RU-38486 had a growth inhibition concentration $50 \%$ or IC50 lower than that of ORG-31710 or CDB-2914 (Fig. 1b). In SK-OV-3 cells, RU-38486 and ORG-31710 had similar growth inhibition potency which was, however, higher than that of CDB-2914 (Fig. 2e). Neither RU-38486 nor ORG-31710 or CDB-2914 showed lethality towards the cells at the $20 \mu \mathrm{M}$ concentration. At the concentration of $40 \mu \mathrm{M}$, however, the three antiprogestins reduced the viability of both cell lines, with the effect being more prominent in OV2008 cells (Fig. 2c) than in SK-OV-3 cells (Fig. 2f).

The cytostatic effect of the $20 \mu \mathrm{M}$ dose of the three antiprogestins was reinforced by the fact that after 72 or $96 \mathrm{~h}$ treatment the cells remained attached to the culture plate, although in a reduced number when compared to vehicle-treated controls (Fig. S1). It is interesting to note that at cytostatic concentrations the antiprogestins not only 

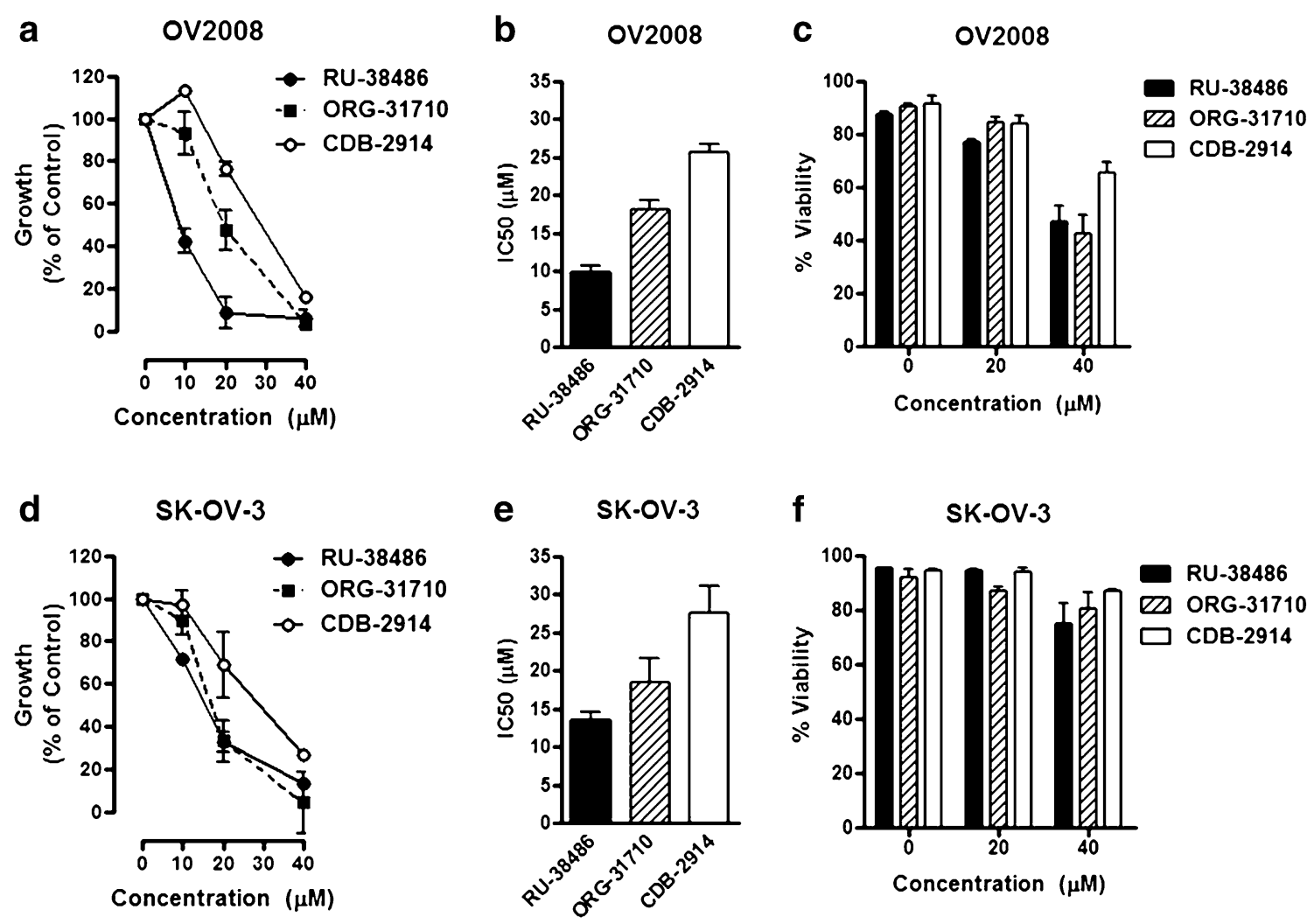

Fig. 2 Effect of antiprogestins on the growth of p53 wild type (OV2008) and p53 null (SK-OV-3) ovarian cancer cells. OV2008 a-c or SK-OV-3 d-f cells were cultured in the presence of the indicated concentrations of RU-38486, ORG-31710, or CDB-2914. The number of cells and their percent viability were recorded at the beginning of the experiment and after 3 days of treatment using exclusion fluorochromes in a microcapillary cytometer. The difference between the number of viable cells in vehicle-treated controls at $0 \mathrm{~h}$ and after 3 days of culture was considered to be $100 \%$. The growth of the treated groups is expressed as percentage of control a and $\mathbf{d}$. For each dose-response curve, the amount of drug needed to achieve $50 \%$ growth inhibition (IC50) was calculated utilizing drug interaction software $\mathbf{b}$ and e. Cell viability is shown in separate graphs (c and $\mathbf{f}$ ). Results are the average of three separate experiments blocked cell proliferation but also altered the morphology of the cells. More evident in SK-OV-3 than in OV2008 cells, the cells acquired an elongated morphology. Conversely, more evident in OV2008 than in SK-OV-3 cells, scattered cells with multi-nucleation and multi-vacuolation were evident (Fig. S1).

When the cell cycle traverse of OV2008 was studied by microcytometric analysis of propidium iodide-labeled DNA particles, it was evident that $20 \mu \mathrm{M}$ antiprogestins had a cytostatic but not a lethal effect. This was indicated by the lack of cellular particles containing hypodiploid (Sub-G1) DNA content, the increased proportion of cells transiting the G0-G1 phase of the cell cycle, which was accompanied by a reduction in the proportion of cells allocated to the $\mathrm{S}$ phase, and no apparent changes in the proportion of cells transiting G2/M (Fig. 3a). When the antiprogestins were used at the $40 \mu \mathrm{M}$ concentration, there was an evident increase in the percentage of hypodiploid-DNA containing cellular particles that was more evident for RU-38486 and ORG-31710 when compared to CDB-1914. The lethality of high concentration antiprogestins was further evidenced for
RU-38486 and ORG-31710 by the reduction in the percentage of cells transiting G0-G1, which was not seen in CDB-2914 that still showed G0-G1 block (Fig. 3a).

To study the dynamics of the cell cycle upon antiprogestin challenge, cell cycle distribution was assessed in OV2008 cells after 12, 24, or $48 \mathrm{~h}$ treatment (Fig. 3b) or in SK-OV-3 cells after 24, 48, 72, or $96 \mathrm{~h}$ treatment (Fig. 4). To link the kinetics of the cell cycle with the growth inhibitory and lethal effects of the compounds, for these time-course studies we utilized the lethal $40 \mu \mathrm{M}$ concentration. In OV2008 cells RU-38486 caused, after $24 \mathrm{~h}$ treatment, Sub-G1 DNA accumulation without any increase in G1, suggesting the cells are likely dying without arresting (Fig. 3b, upper panels, and lower left panel); however, the same concentration of ORG-31710 and CDB2914 caused G1 arrest after 12 and $24 \mathrm{~h}$ treatment (Fig. 3b, upper panels). ORG-31710 showed Sub-G1 accumulation beginning at $48 \mathrm{~h}$ exposure with a parallel decline in $\mathrm{G} 1$, whereas CDB-2914 still showed G1 arrest $48 \mathrm{~h}$ after treatment (Fig. 3b, lower left panel). The three compounds abrogated growth as indicated by the stagnant cell number 


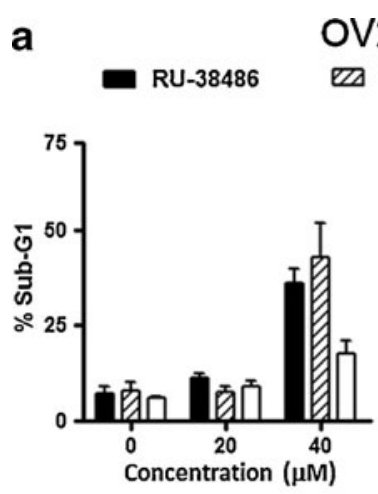

CDB-2914
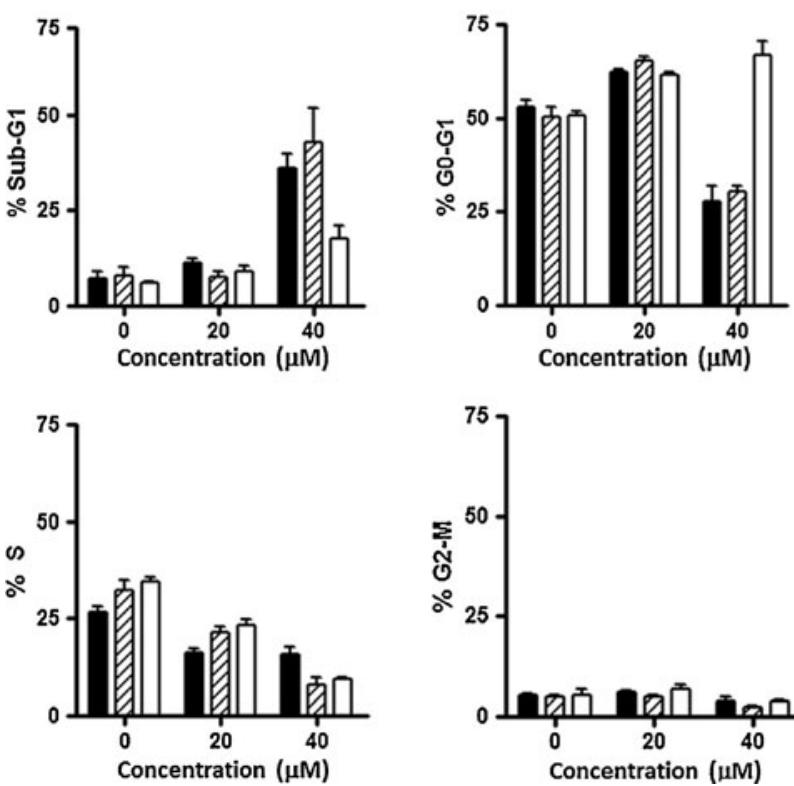

b
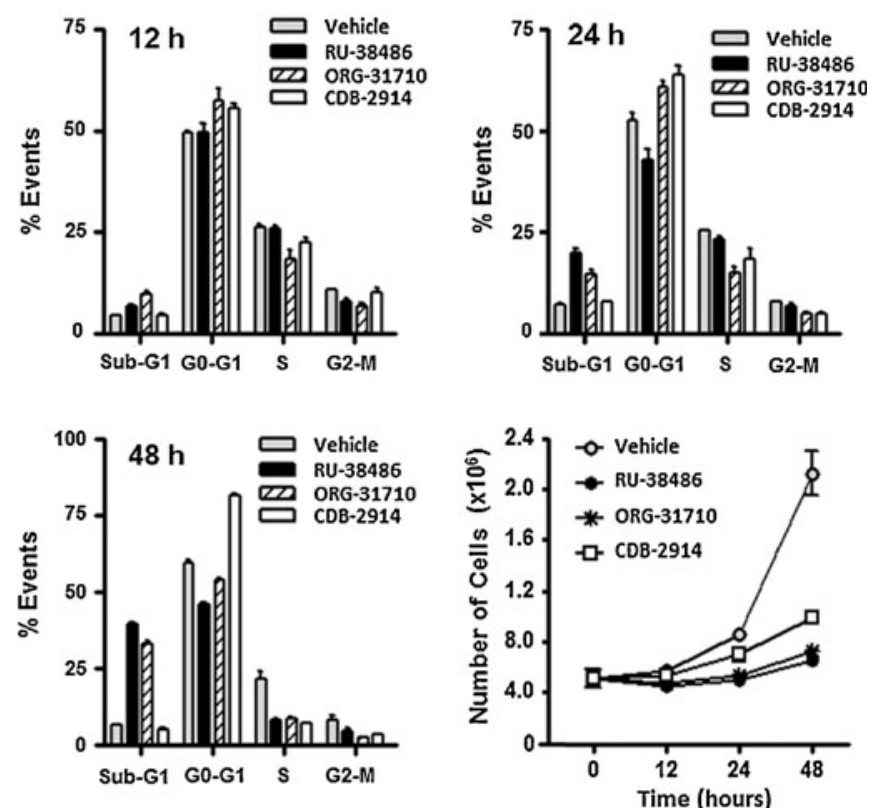

Fig. 3 Effect of antiprogestins on cell cycle distribution in OV2008 cells. a Logarithmically growing OV2008 ovarian cancer cells were exposed to 0,20 or $40 \mu \mathrm{M}$ RU-38486, ORG-31710 or CDB-2914 for $72 \mathrm{~h}$. The percentage of cells with Sub-G1 DNA content (upper left), or with DNA content consistent with G0-G1 (upper right), S (lower left), and G2-M (lower right) phases of the cell cycle was determined by microcapillary cytometric analysis after propidium iodide staining of the DNA. b Logarithmically growing OV2008 cells were exposed

in the treated groups along the study (Fig. 3b, lower right panel). In SK-OV-3 cells, the kinetics of the cell cycle was slightly different. Twenty-four, 48 or $72 \mathrm{~h}$ after treatment with any of the compounds, the cells accumulated in G1 with a reduced proportion of cells still in $\mathrm{S}$ phase when compared to vehicle-treated controls (Fig. 4a-c). After $96 \mathrm{~h}$, however, the three antiprogestins triggered accumulation of Sub-G1 DNA particles when compared to the values at $72 \mathrm{~h}$ (Fig. 4d). The three compounds abrogated growth along the study when compared to vehicle-treated controls (Fig. 4e).

Lethal concentrations of antiprogestins induce morphological and biochemical changes consistent, at least in part, with apoptotic cell death

After culturing OV2008 or SK-OV-03 cells with $20 \mu \mathrm{M}$ antiprogestins, no lethality was observed; however, signs of loss of viability were found at the $40 \mu \mathrm{M}$ concentration (Figs. 2c and f, 3a and b, and 4). Morphological studies show that the number of OV2008 cells still adherent after $96 \mathrm{~h}$ treatment with $40 \mu \mathrm{M}$ antiprogestins is minimal, yet with differences among the treatments, with the effects being those of RU-38486 > ORG-31710 > CDB-2914. The

to DMSO (vehicle) or $40 \mu \mathrm{M}$ antiprogestins for $12 \mathrm{~h}$ (upper left), $24 \mathrm{~h}$ (upper right), or $48 \mathrm{~h}$ (lower left). The percentage of events consistent with Sub-G1, G0-G1, S, and G2-M DNA content was analyzed after propidium iodide staining utilizing microcapillary cytometry. The number of cells was recorded at the beginning of the experiment and after different periods of incubation with or without treatments (lower right)

majority of the cells at this point in time appear detached and with morphological features similar to those shown by cisplatin-treated cells (Fig. 5a). SK-OV-3, although less sensitive to the lethal effects of the antiprogestins, show a remarkably reduced number of still adherent cells after $96 \mathrm{~h}$ treatment with a concomitant enhanced number of floating cells with similar morphological features to those shown by cisplatin-treated cells (Fig. 5b). Fragmentation of the DNA was clearly observed after $60 \mathrm{~h}$ exposure to $40 \mu \mathrm{M}$ RU38486 and ORG-31710 in OV2008 cells, whereas the effect was less pronounced in CDB-2914-treated cells at the same point in time (Fig. 5c, left panel). For SK-OV-3 cells, treatment with $40 \mu \mathrm{M}$ of the three compounds showed DNA laddering upon $120 \mathrm{~h}$ incubation (Fig. 5c, right panel).

To further explore the signaling molecules involved in the lethal action of antiprogestins in ovarian cancer cells, we treated OV2008 cells with $40 \mu \mathrm{M}$ antiprogestins and collected whole cell extracts after 24,48 or $72 \mathrm{~h}$ incubation. Results in Fig. 5d show that RU-38486 caused cleavage of the full-length caspase-3, $116 \mathrm{kDa}$ PARP substrate into the $86 \mathrm{kDa}$ cleaved and inactive form $24 \mathrm{~h}$ after treatment, an effect that was more evident at $48 \mathrm{~h}$, in association with down-regulation of cell cycle 


\section{SK-OV-3}

a

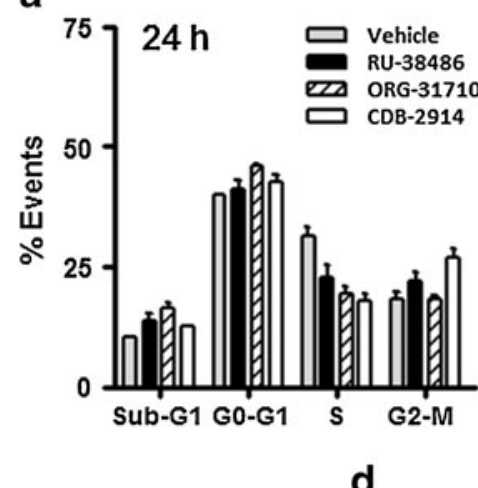

b

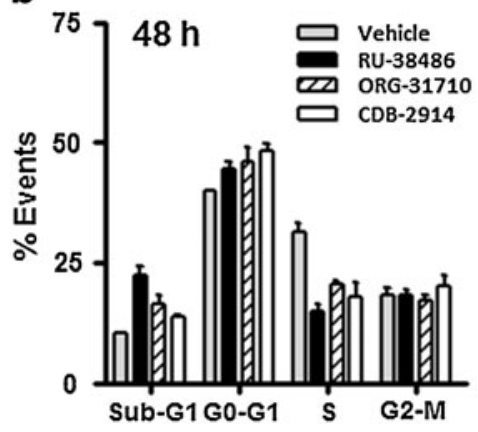

C

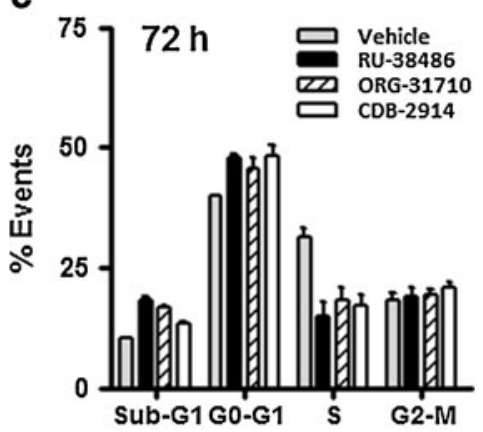

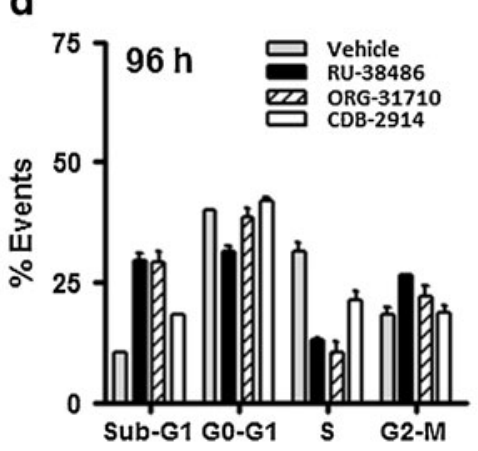

e

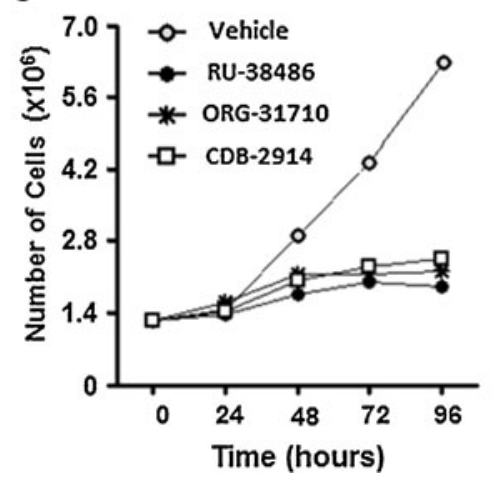

Fig. 4 Effect of antiprogestins on cell cycle distribution in SK-OV-3 cells. Logarithmically growing SK-OV-3 cells were exposed to DMSO (vehicle) or $40 \mu \mathrm{M}$ RU-38486, ORG-31710 or CDB-2914 for $24 \mathrm{~h} \mathrm{a}, 48 \mathrm{~h} \mathrm{~b}, 72 \mathrm{~h} \mathrm{c}$ or $96 \mathrm{~h} \mathrm{~d}$. The percentage of events consistent with Sub-G1, G0-G1, S, and G2-M DNA content was

related proteins $\mathrm{Cdk}-2$ and $\mathrm{p} 21^{\mathrm{cip} 1}$, and cleavage of p2 $7^{\text {kip1 }}$. RU-38486-induced lethality was associated with down-regulation of the inhibitor of apoptosis protein XIAP but, curiously, it occurred in the presence of high levels of anti-apoptotic protein Bcl-2 when compared to vehicle-treated controls. ORG-31710-induced cell death associated with PARP cleavage and down-regulation of Cdk-2, in the presence of high levels of Cdk inhibitors $\mathrm{p} 21^{\text {cip } 1}$ and $\mathrm{p} 27^{\mathrm{kip} 1}$. In contrast to RU-38486, ORG31710-induced cytotoxicity occurred with higher levels of XIAP and no changes in Bcl-2 when compared to vehicle-treated controls. Finally, lethality associated to CDB-2914 occurred with up-regulation and cleavage of PARP, up-regulation of XIAP, and up-regulation and cleavage of $\mathrm{Bcl}-2$, in the presence of high levels of $\mathrm{p} 21^{\text {cip } 1}$ and $\mathrm{p} 27^{\mathrm{kip} 1}$. Altogether results in Fig. 5 suggest that concentrations of antiprogestins higher than $20 \mu \mathrm{M}$ are lethal to p53-wild type OV2008 and p53-null SK-OV3 ; the molecular mediators of the cell death mechanisms, as well as their interrelationship with cell cycle regulatory proteins, differ among the antiprogestins and warrant further investigations. analyzed after propidium iodide staining utilizing microcapillary cytometry. The number of cells was recorded at the beginning of the experiment and after different periods of incubation with or without treatments e

Cytostatic concentrations of antiprogestins increase association of $\mathrm{p} 21^{\mathrm{cip} 1}$ and $\mathrm{p} 27^{\mathrm{kip} 1}$ with Cdk-2, promote nuclear localization of $\mathrm{p} 21^{\mathrm{cip} 1}$ and $\mathrm{p} 27^{\mathrm{kip} 1}$, reduce nuclear abundances of Cdk-2 and cyclin E, and inhibit the activity of Cdk-2

In association with cyclin $\mathrm{E}, \mathrm{Cdk}-2$ is essential to drive the cell cycle through the G1-S transition and into the S phase whereas $\mathrm{p} 21^{\mathrm{cip} 1}$ and $\mathrm{p} 27^{\mathrm{kip} 1}$ are usually involved in inhibiting cyclin E/Cdk-2 activity [29]. We questioned whether the activity of Cdk-2 was related to the growth inhibitory effect of the antiprogestins. OV2008 cells were cultured for 12,24 , or $48 \mathrm{~h}$ in the presence of $20 \mu \mathrm{M}$ RU38486, ORG-31710, or CDB-2914 (Fig. 6a). Twelve hours after treatment with RU-38486, p2 $1^{\text {cip1 }}$ levels increased with respect to vehicle-treated controls. Such increase was even higher $24 \mathrm{~h}$ later, and persisted $48 \mathrm{~h}$ following drug exposure. Treatment with ORG-31710 also led to an increase in $\mathrm{p} 21^{\text {cip } 1}$ levels $12 \mathrm{~h}$ after exposure, a further increase at $24 \mathrm{~h}$, but it was followed by a decline at $48 \mathrm{~h}$. Finally, CDB-2914 induced a mild increase in p $21^{\text {cip } 1}$ levels at $12 \mathrm{~h}$, followed by higher levels at $24 \mathrm{~h}$ and a further 


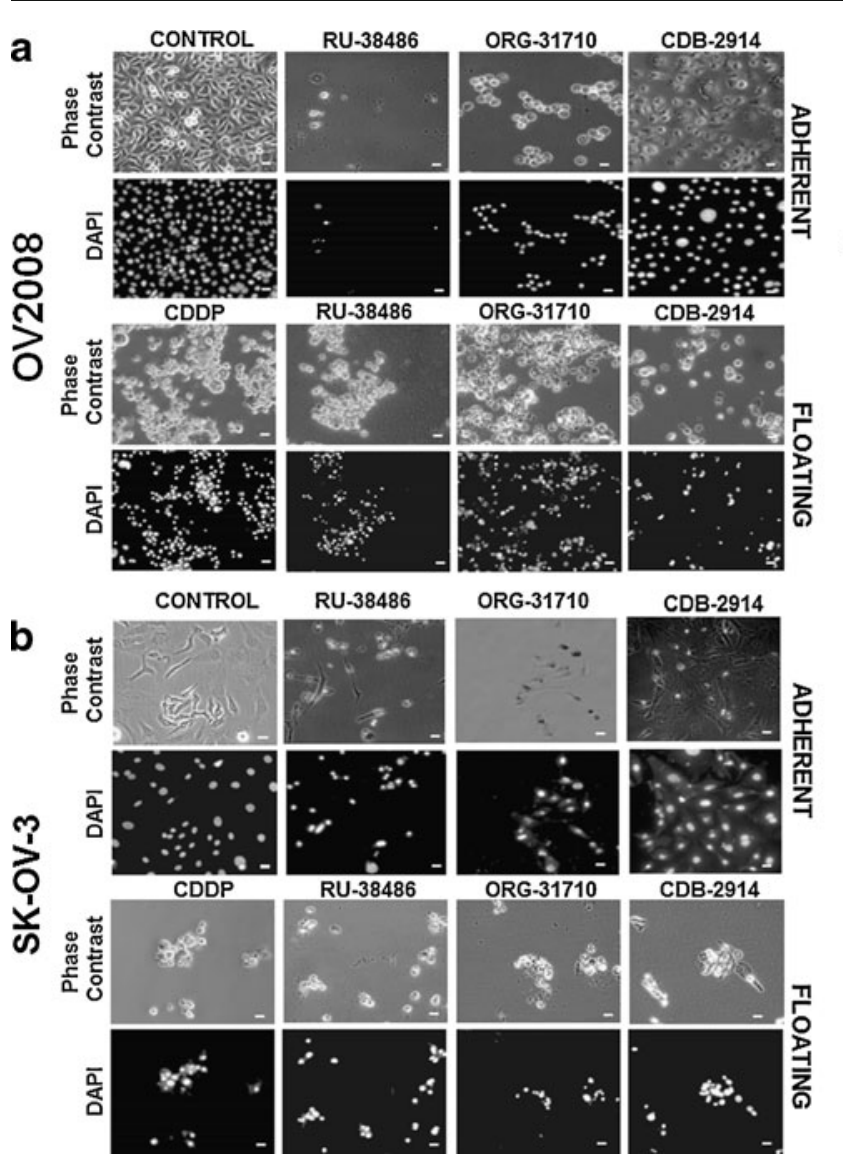

Fig. 5 Lethality of antiprogestins towards ovarian cancer cells. OV2008 or SK-OV-3 cells were cultured in the presence of $40 \mu \mathrm{M}$ RU-38486, ORG-31710 or CDB-2914. After $60 \mathrm{~h}$ (OV2008) or $120 \mathrm{~h}$ (SK-OV-3), floating cells were collected, adhered to a microscope slide, stained with DAPI, and microscopic phase contrast and fluorescence images were obtained from the same fields. As positive control of apoptotic cell death, floating cells from cisplatin (CDDP) treated cells were included in the morphological studies a and $\mathbf{b}$. Adherent untreated cells are also shown (CONTROL). Scale bar, $20 \mu \mathrm{m}$. c A similar experiment was done in which all floating and

increase at $48 \mathrm{~h}$. A similar pattern of induction was observed for $\mathrm{p} 27^{\text {cip1 }}$ with small differences. RU-38486 induced a slight increase in $\mathrm{p} 27^{\mathrm{kip} 1}$ levels at $12 \mathrm{~h}$ but a larger increase at 24 and $48 \mathrm{~h}$, whereas ORG-31710 needed $24 \mathrm{~h}$ exposure to increase p2 $7^{\text {cip } 1}$, and CDB-2914 only slightly increased $\mathrm{p} 27^{\mathrm{cip} 1}$ levels even after $48 \mathrm{~h}$ exposure. No major modification in the total protein levels of Cdk-2 and cyclin $\mathrm{E}$ was observed in these experiments. When a similar experiment was conducted in SK-OV-3 cells $\mathrm{p} 21^{\text {cip } 1}$ and $\mathrm{p} 27^{\mathrm{kip} 1}$ increased in response to the antiprogestins as well, but there was a pronounced decline in the abundance of Cdk-2 not observed in OV2008 cells (Fig. S2).

Because nuclear localization of Cdk-2 is required for its full activation and cell cycle progression [30, 31], we analyzed whether the antiprogestins affect the nucleocytoplasmic trafficking of the $\mathrm{Cdk}$ inhibitors $\mathrm{p} 21^{\mathrm{cip} 1}$ and p2 $7^{\text {kip } 1}$, cyclin E and Cdk-2. OV2008 cells treated with
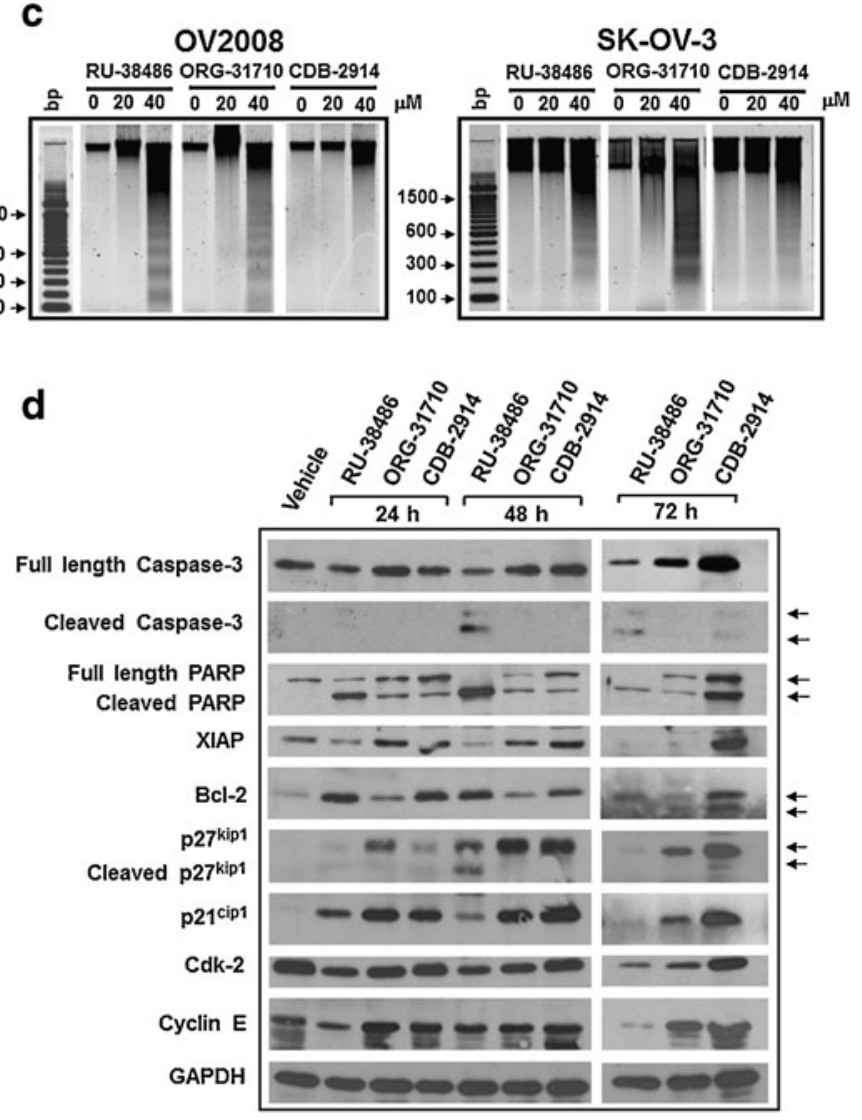

attached cells were pelleted, total DNA was isolated, subjected to agarose electrophoresis, stained with SYBR Gold nucleic acid stain, and photographed with the Amersham Typhoon fluorescence imaging system. A 100 base pair (bp) marker was run in parallel. (d) OV2008 cells were exposed to DMSO (Vehicle) or $40 \mu \mathrm{M}$ RU-38486, ORG31710 or CDB-2914 for $72 \mathrm{~h}$. Whole protein extracts were obtained and separated by electrophoresis, and immunoblots were probed with the indicated antibodies to recognize cell cycle and cell death related proteins. The housekeeping gene GAPDH was used as protein loading control

vehicle or $20 \mu \mathrm{M}$ antiprogestins for $48 \mathrm{~h}$ were subjected to subcellular fractionation and Western blot analysis. Results in Fig. $6 \mathrm{~b}$ reveal that the antiprogestins induced an increase in nuclear localization of $\mathrm{p} 21^{\mathrm{cip} 1}$ and $\mathrm{p} 27^{\mathrm{kip} 1}$, which correlated with decreased Cdk-2 and cyclin E nuclear levels. As a consequence of the observed decrease in Cdk-2 and cyclin E nuclear abundance, together with the increase in the abundances of Cdk inhibitors, we asked whether such changes were reflected in the modulation of the activity of Cdk-2. We immunoprecipitated Cdk-2 from vehicle-treated OV2008 cells or from OV2008 cells treated with $20 \mu \mathrm{M}$ antiprogestins for $48 \mathrm{~h}$ and did an in vitro kinase assay using histone $\mathrm{H} 1$ as substrate. The results in Fig. $6 \mathrm{c}$ show that the activity of Cdk-2 was inhibited in both nucleus and cytoplasm, and such inhibition was stronger when the cells were exposed to RU-38486 or ORG-31710, whereas CDB-2914 caused the weakest 
a

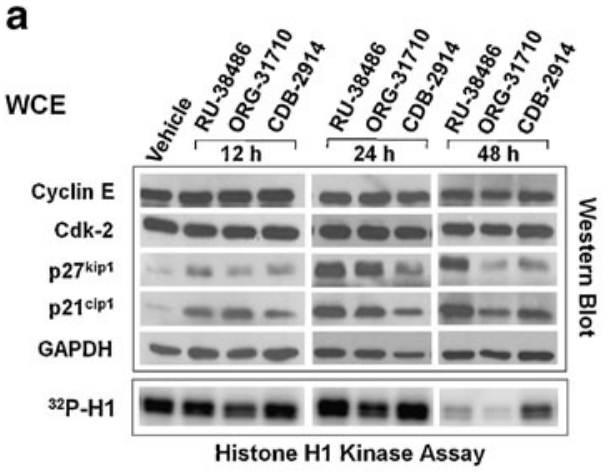

b

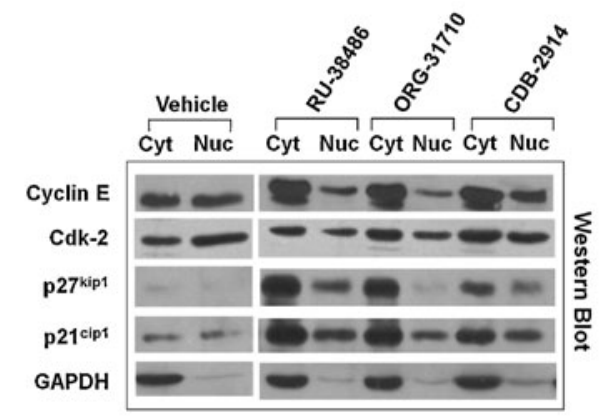

C

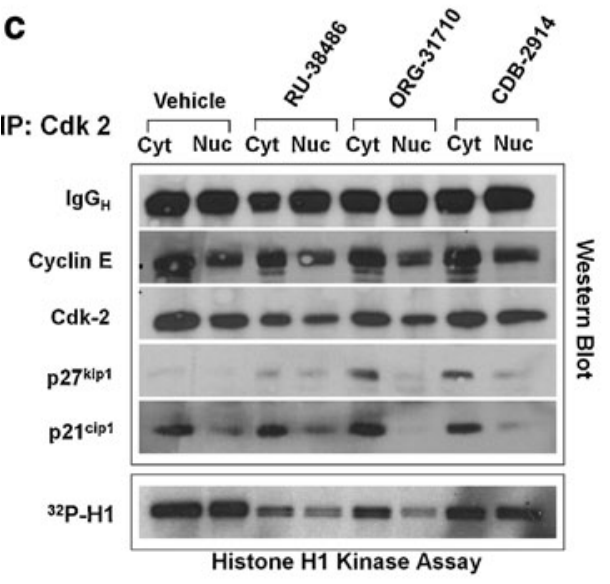

d

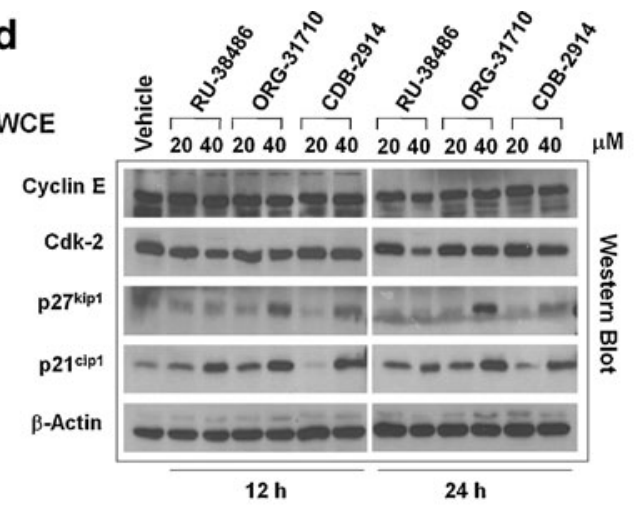

e
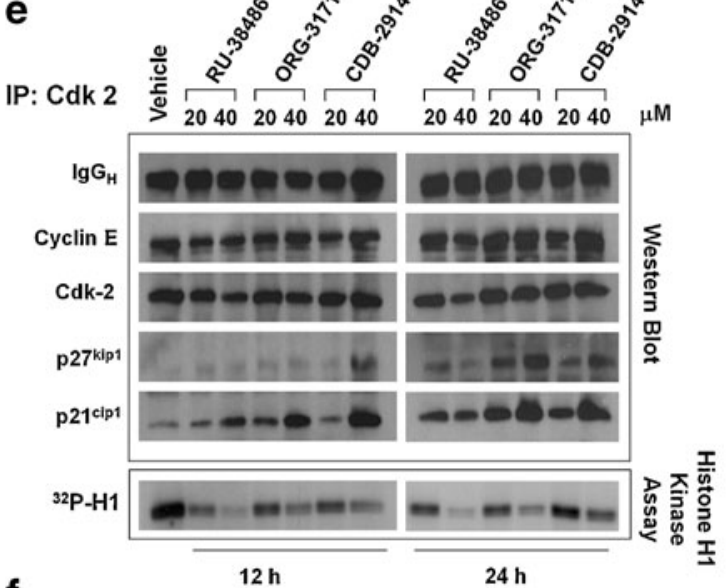

IP: Cdk 2

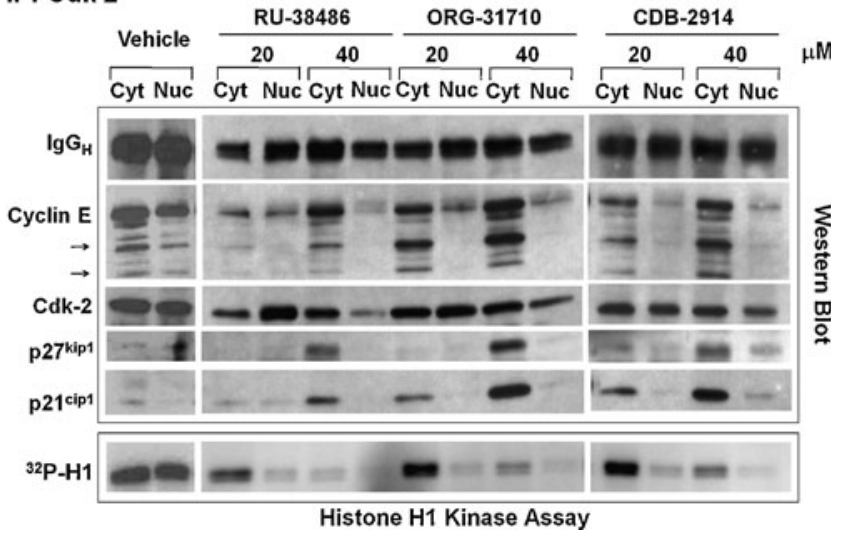

Fig. 6 Effect of antiprogestins on cell cycle regulatory proteins in ovarian cancer cells. OV2008 cells were exposed to DMSO (Vehicle), 20 a-e or $40 \mu \mathrm{M}$ d and e RU-38486, ORG-31710, or CDB-2914 for the indicated times a, d, and e or $48 \mathrm{~h} \mathrm{~b}$ and c. a Whole protein extracts (WCE) were obtained and separated by electrophoresis, and immunoblots were probed with the indicated cell cycle related antibodies. Whole protein extracts were also immunoprecipitated with anti-Cdk-2 antibody and assayed for their capacity to phosphorylate histone $\mathrm{H} 1$ in vitro in the presence of ${ }^{32} \mathrm{P}$ ATP. b Isolation of nuclear and cytosolic fractions was achieved, proteins from each fraction were obtained and separated by electrophoresis, and immunoblots were probed with the indicated antibodies. $\mathbf{c}$ Nuclear and cytosolic extracts were imunoprecipitated with anti-Cdk-2 antibody, electrophoresed, and probed with the indicated antibodies. The immunoprecipitates were also assayed for their capacity to phosphorylate histone $\mathrm{H} 1$ in vitro in the presence of ${ }^{32} \mathrm{P}$ ATP. d Time-course experiment on the effect of 20 or $40 \mu \mathrm{M}$ antiprogestins on the expression of cell cyclerelated proteins. e Whole cell extracts from previous experiment were imunoprecipitated with anti-Cdk-2 antibody, electrophoresed, probed with the indicated antibodies, and also assayed for their capacity to phosphorylate histone $\mathrm{H} 1$ in vitro. f A similar experiment was performed as in $\mathbf{d}$ but instead of WCE, nuclear and cytoplasmic protein extracts were isolated and immunoprecipitated with Cdk-2 antibody upon treatment of the cells with 20 or $40 \mu \mathrm{M}$ antiprogestins for $24 \mathrm{~h}$ 
inhibition. There was an increase in the amounts of $\mathrm{p} 21^{\mathrm{cip} 1}$ and $\mathrm{p} 27^{\mathrm{kip} 1}$ that co-immunoprecipitated with Cdk-2, which was more pronounced in the cytoplasm than in the nucleus, suggesting that the inhibition in Cdk-2 activity is at least in part likely due to an increase in the binding of the inhibitors $\mathrm{p} 21^{\text {cip } 1}$ and $\mathrm{p} 27^{\mathrm{kip} 1}$. The activity of Cdk-2 was also remarkably inhibited in both nucleus and cytoplasm of SKOV-3 cells as shown when treated with RU-38486 (Fig. S3).

The magnitude of the increase in $\mathrm{p} 21^{\mathrm{cip} 1}$ and $\mathrm{p} 27^{\mathrm{kip} 1}$ and the decline in Cdk-2 levels induced by the antiprogestins was dose-dependent, with the particularity that the increase in $\mathrm{p} 21^{\text {cip } 1}$ occurred earlier than that of p2 $7^{\mathrm{kip} 1}$ (Fig. 6d). When Cdk-2 was immunoprecipitated, there was a dosedependent increase in the amounts of $\mathrm{p} 21^{\mathrm{cip} 1}$ and $\mathrm{p} 27^{\mathrm{kip} 1}$ that co-immunoprecipitated with $\mathrm{Cdk}-2$, which was associated with a parallel decline in the activity of Cdk-2 (Fig. 6e). A dose- and time-dependent inhibition of Cdk-2 activity was also observed in SK-OV-3 cells when exposed to 20 or $40 \mu \mathrm{M}$ ORG-31710 (Fig. S4).

In addition to the increased association of Cdk inhibitors $\mathrm{p} 21^{\mathrm{cip} 1}$ and $\mathrm{p} 27^{\mathrm{kip} 1}$ to Cdk-2, another contributing factor for the reduced Cdk-2 activity in response to antiprogestins appears to be a decline in the nuclear levels of cyclin $\mathrm{E}$ (Fig. 6b). To further confirm this assumption we immunoprecipitated Cdk-2 from cytosolic and nuclear fractions of OV2008 cells, which had been exposed for $24 \mathrm{~h}$ to 20 or $40 \mu \mathrm{M}$ antiprogestins. Fig. 6f shows an evident dosedependent decline in Cdk-2 activity in both cellular compartments, together with a major decline in cyclin $\mathrm{E}$ nuclear levels, and cyclin E redistribution to the cytoplasm, where lower molecular weight cyclin $\mathrm{E}$ fragments were also observed. The association of $\mathrm{p} 21^{\mathrm{cip} 1}$ and $\mathrm{p} 27^{\mathrm{kip} 1}$ to Cdk-2 in the cytoplasmic fraction correlated with the decline in the activity of Cdk-2 in this cellular compartment even in the presence of cyclin $\mathrm{E}$, which however may be undergoing accelerated proteasomal degradation. In the nuclear fraction, however, the correlation among binding of $\mathrm{Cdk}$ inhibitors to Cdk-2 and decline in Cdk-2 activity is not apparent, suggesting that it may be the lack of cyclin $\mathrm{E}$ rather than the increase in Cdk inhibitors the main cause for the blunted activity of Cdk-2 in the nucleus.

The dose-dependent decline in Cdk-2 activity observed in OV2008 cells (Fig. 6e and f), and SK-OV-3 (Fig. S4), correlated with a dose-dependent growth inhibitory effect elicited by the antiprogestins (Fig. 2 and Fig. S5). Altogether these results suggest that the dose-dependent antiprogestin-mediated inhibition of growth in ovarian cancer cells involves increased nuclear abundance of the Cdk inhibitors $\mathrm{p} 21^{\mathrm{cip} 1}$ and $\mathrm{p} 27^{\mathrm{kip} 2}$, decreased Cdk-2 and cyclin $\mathrm{E}$ nuclear levels, redistribution of cyclin $\mathrm{E}$ to the cytoplasm, and a remarkable decline in the activity of the cell cycle regulatory protein $\mathrm{Cdk}-2$ in both nuclear and cytoplasmic compartments.

\section{Discussion}

Ovarian cancer is known as a silent killer due to its late detection and high mortality. Despite countless efforts to develop early diagnostic tools and new treatment approaches, the 5-year survival for these patients has only improved from $37 \%$ to $45 \%$ in the past 30 years [32]. To cure this disease efforts are geared to chemoprevention and assessment of risk factors, early detection biomarkers, identification of early disease symptoms, and development of targeted drugs to accompany standard therapy [33]. However, since screening strategies for early diagnosis have so far failed and most patients still die from the disease, new therapeutic options are desperately needed. The results presented in this work clearly show that three different antiprogestin compounds are cytotoxic to ovarian cancer cells displaying two main effects: (i) a cytostatic effect at lower concentrations blocking cell growth at the G1 phase of the cell cycle; and (ii) a lethal effect at higher doses associated with morphological features of apoptosis and fragmentation of the genomic DNA. The overall toxicity of antiprogestins involved a dose-dependent decline in the activity of the cell cycle regulatory protein Cdk2 (Fig. 7).

Cdk-2 has been shown to be critical in promoting the transition of cells in the cell cycle from G1 to S phase [29]. For instance, cyclin E/Cdk-2 is needed for the stimulation of histone gene transcription [34], which is one of the major events that mark the entry into the $\mathrm{S}$ phase. To drive cell cycle progression, Cdk-2 should be free of $\mathrm{p} 21^{\mathrm{cip} 1}$ and p2 $7^{\text {kip } 1}$ binding [29], bound to cyclin E, and allocated to the nucleus to phosphorylate cell cycle regulatory proteins [31, 35]. We show that antiprogestins affect the nucleocytoplasmic trafficking of Cdk inhibitors p $21^{\mathrm{cip} 1}$ and p $27^{\mathrm{kip} 1}, \mathrm{Cdk}-2$ and its co-factor cyclin E. We demonstrate that antiprogestins increase $\mathrm{p} 21^{\mathrm{cip} 1}$ and $\mathrm{p} 27^{\mathrm{kip} 1}$ abundances in both cytoplasm and nuclear compartments, which correlate with decreased Cdk-2 and cyclin E nuclear levels, increased cytoplasmic cyclin $\mathrm{E}$ and a remarkable decline in the activity of Cdk-2 in both subcellular compartments. The magnitude of inhibition of Cdk-2 activity was related to the growth inhibition potency of the compounds with RU$38486>$ ORG-31710 > CDB-2914. Supporting our results, a decline in cyclin E-associated kinase activity (presumably Cdk-2) has been previously reported for T-47D breast cancer cells in response to ORG-31710 in the absence of significant changes in cyclin $\mathrm{E}$ and Cdk levels, but in the presence of elevated concentrations of $\mathrm{p} 21^{\text {cip } 1}$, suggesting that $\mathrm{p} 21^{\mathrm{cip} 1}$ contributes to the reduction in Cdk-2 activity after antiprogestin treatment [9]. In ovarian cancer cells we show that not only the increased association of $\mathrm{p} 21^{\mathrm{cip} 1}$ and p $27^{\text {kip } 1}$ to $\mathrm{Cdk}-2$ may account for the reduced Cdk-2 activity in the nucleus in response to antiprogestins, but 
a

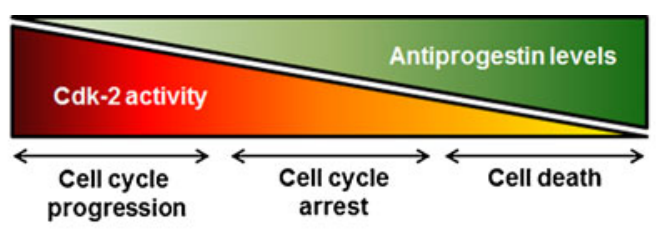

b

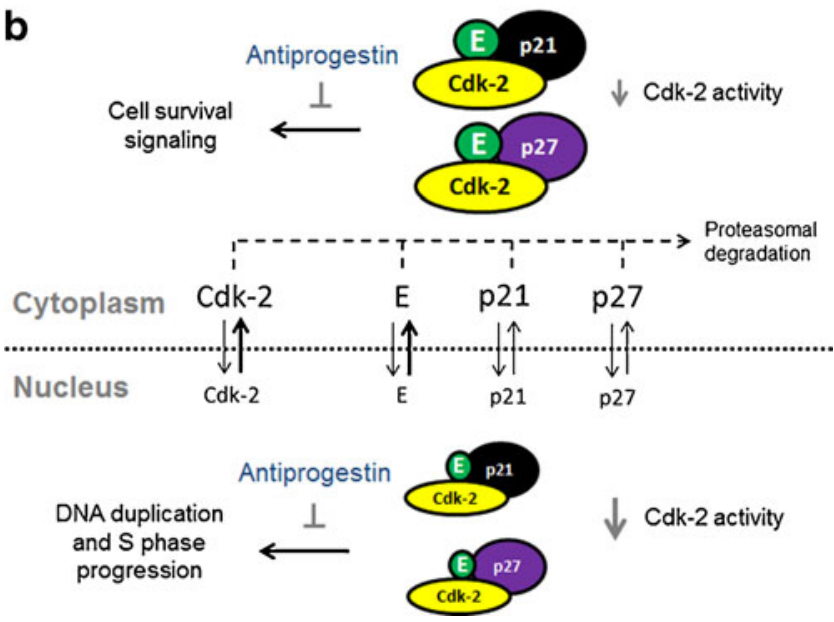

Fig. 7 Proposed model for the cytotoxic effect of antiprogestins in ovarian cancer cells. a In normal growing conditions or in the presence of very low doses of antiprogestins, the activity of Cdk-2 is elevated and the cell cycle progresses. At certain threshold of antiprogestin levels, the activity of Cdk-2 is reduced in association with cytostasis. At higher doses of antiprogestins, Cdk-2 activity is blunted leading to cell death. b Antiprogestins reduce nuclear and cytoplasmic activity of Cdk-2 in association with up-regulation of Cdk-2 inhibitors p2 $1^{\text {cip } 1}$ (p21) and p2 $7^{\text {kip1 }}$ (p27), down-regulation of Cdk-2 and cyclin E in the nucleus, and cyclin E redistribution to the cytoplasm where it may undergo accelerated proteasome degradation. The inhibition of nuclear activity of Cdk-2 leads to G1 cell cycle arrest due to abrogation of Cdk-2 driven pathways needed for DNA duplication and $\mathrm{S}$ phase progression. The inhibition of cytoplasmic Cdk-2 activity, when bypassing certain minimal activity threshold, ultimately leads to cell death likely due to abrogation of a Cdk-2 dependent cell survival pathway

also a reduction in Cdk-2 and cyclin E nuclear levels and redistribution of cyclin $\mathrm{E}$ to the cytoplasm, are related variables leading to blunting Cdk-2 nuclear activity needed for $\mathrm{G} 1$ to $\mathrm{S}$ transition. A recent study using $\mathrm{LNCaP}$ prostate cancer cells revealed that targeting Cdk2 to the nucleus is sufficient to prevent growth inhibition triggered by $1,25(\mathrm{OH})_{2}$ D3 [36], suggesting that antiprogestin-mediated growth inhibition and growth arrest triggered by metabolites of vitamin D may share common molecular intermediaries.

Because Cdk-2 is frequently up-regulated in ovarian tumors [37], the potent inhibition of Cdk-2 elicited by antiprogestins may be critically important from a translational therapeutics viewpoint. Moreover, because cytoplasmic localization of Cdk inhibitor $\mathrm{p} 27^{\mathrm{kip} 1}$ in ovarian cancer patients has been associated with poor prognosis [38], by promoting an increase in $\mathrm{p} 27^{\mathrm{kip} 1}$ in the nucleus, antipro- gestins may be able to rescue the tight inhibitory control of Cdk inhibitors on Cdk-2 activity which is frequently lost in ovarian cancer. One question that deserves an answer is whether $\mathrm{p} 21^{\mathrm{cip} 1}$ and/or $\mathrm{p} 27^{\mathrm{kip} 1}$ that accumulate after antiprogestin exposure are required for antiprogestinmediated Cdk-2 inhibition and/or cell cycle arrest, or whether it is the decline in nuclear cyclin $\mathrm{E}$ levels itself sufficient to cause the reduction in nuclear Cdk-2 activity. In support of the latter hypothesis overexpression of cyclin $\mathrm{E}$ in $\mathrm{LNCaP}$ prostate cancer cells blocked 1, $25(\mathrm{OH})_{2} \mathrm{D} 3-$ mediated growth inhibition, Cdk-2 relocalization to the cytoplasm, and inhibition of Cdk-2 activity [36], suggesting that a similar mechanism may be taking place in ovarian cancer cells upon antiprogestin treatment. Because in mammalian cells cyclin $\mathrm{E}$ is degraded in an ubiquitin- and proteasome-dependent pathway $[39,40]$, it is possible that by causing cyclin $\mathrm{E}$ redistribution to the cytoplasm antiprogestins promote cyclin E proteasomal degradation. This pharmacologic engagement of the proteasome system degrading G1 cyclins such as D1 and E has been previously proposed as a molecular target for cancer therapy [41].

A potential target of antiprogestin action is the ubiquitinproteasome system (UPS). This idea is based on the following facts: (i) to transition from G1 to S phase and to commit to DNA synthesis, the cells must degrade the Cdk-2 inhibitors $\mathrm{p} 27^{\mathrm{kip} 1}$ and $\mathrm{p} 21^{\text {cip }}$ via the Skp1-Cullin-Fbox protein/Skp2 $\left(\mathrm{SCF}^{\mathrm{Skp} 2}\right)$ E3 ubiquitin ligase complex $[42,43]$. This requires the Cdk-2-dependent phosphorylation of $\mathrm{p} 27^{\mathrm{kip} 1}$ on Thr187 [42] and $\mathrm{p} 21^{\text {cip } 1}$ on Ser130 [43]; (ii) antiprogestins have a dual effect blocking Cdk-2 activity and triggering the accumulation of $\mathrm{p} 21^{\text {cip } 1}$ and $\mathrm{p} 27^{\mathrm{kip} 1}$, and these Cdk-2 inhibitors rely on the UPS for their disappearance to enforce the orderly progression of the cell cycle from $\mathrm{G} 1$ to the $\mathrm{S}$ phase; (iii) finally, there are remarkable similarities in the behavior of antiprogestins and proteasome inhibitors in inducing $\mathrm{p} 21^{\mathrm{cip} 1}$ and $\mathrm{p} 27^{\mathrm{kip} 1}$ accumulation before triggering caspase-associated lethality $[18,19,44]$. It is therefore possible that antiprogestins induce $\mathrm{G} 1$ growth arrest by interfering with the proteasome-mediated degradation of $\mathrm{p} 27^{\mathrm{kip} 1} / \mathrm{p} 21^{\mathrm{cip} 1}$, leading to Cdk-2 inhibition. It is also feasible that the sustained levels of $\mathrm{p} 27^{\mathrm{kip}}$ and $\mathrm{p} 21^{\mathrm{cip} 1}$ in response to cytostatic doses of antiprogestins are the consequence of a reduced recognition of the Cdk inhibitors by the UPS. Because ovarian cancer cells function with high activity of the UPS [44], this proteolytic machinery may be degrading Cdk inhibitors at a high rate, causing the reduced basal levels we found in ovarian cancer cells, thus favoring their proliferation. Antiprogestins may mitigate this process.

In addition to regulating cell cycle progression, Cdk-2 is involved in cell survival after DNA damage and in DNA repair pathways $[45,46]$. As a survival factor, for instance, Cdk-2 phosphorylates the FOXO1 transcription activator of 
pro-apoptotic genes, keeping them in the cytoplasm [45, 47]. If the activity of Cdk-2 is abolished by an antiprogestin, then FOXO1 may not be retained in the cytoplasm, consequently migrating to the nucleus where it promotes the expression of pro-apoptotic genes [45, 47]. The lethality of high concentration antiprogestins associated with features of apoptosis as compared to platinuminduced lethality in the same cell lines in terms of nuclear and DNA fragmentation. However, the molecular mediators of antiprogestin-mediated cell death varied among the steroids. Although cleavage of the caspase- 3 substrate PARP was a commonality among RU-38486, ORG-31710 and CDB-2914, the latter also caused an upregulation of PARP which was also previously observed in cultured human uterine leiomyoma cells [24]. In addition, CDB-2914 caused up-regulation of the antiapoptotic proteins XIAP and Bcl-2, yet cell death still ensued but with less effectiveness than that observed after exposure to high concentrations of RU-38486 or ORG31710 in which both XIAP and Bcl-2 are down-regulated after 3 days of treatment. Thus, the extended up-regulation of XIAP and Bcl-2 upon CDB-2914 treatment but not after RU-38486 or ORG-31710 may account for the reduced cytotoxic potency of CDB-2914. Although with different potencies, high concentrations of antiprogestins were able to lead the cells to crossing a cell death threshold or point of no return in which the pro-apoptotic load of the cell surpasses its anti-apoptotic buffering capacity.

Apoptosis induced by antiprogestins has also been reported in cultured human periovulatory granulosa cells in which RU-38486 and ORG-31710 caused an increase in the activity of executer caspase- 3 and fragmentation of the DNA [26]. RU-38486 was also shown to cause apoptosis in breast, cervical, endometrial, and prostate cancer cells in association with activation of caspase-3, down-regulation of Bcl-2 and secretion of TGF $\beta 1$ [14, 48, 49]. Using ovarian cancer cell lines, our work expanded to CDB-2914 the previously reported cytotoxicity of RU38486 and ORG-31710.

It is unknown whether antiprogestins inhibit cell growth involving progesterone receptors (PR), glucocorticoid receptors (GR) or neither one of them. In fact it has been previously suggested a dissociation between the antihormone and anti-proliferative activity of antiprogestins [50]. This is further supported by studies in MDA-MB-231 breast cancer cells lacking both ER and PR, in which RU38486 retained its antiproliferative activity [14]. On the other hand, our laboratory using SK-OV-3 cells [18] and others using SV-40 transformed ovarian cystadenoma cells [51] have shown that RU-38486 elicits progesterone-like effects in terms of growth inhibition although with greater potency than progesterone, whereas others [52] using HOC7 ovarian carcinoma cells demonstrated that high concen- tration $(30 \mu \mathrm{M})$ progesterone stimulates $\mathrm{p} 21^{\mathrm{cip} 1}$ and $\mathrm{p} 27^{\mathrm{kip} 1}$ expression and inhibit Cdk-2 activity mimicking our observations with antiprogestins. Whether progesterone and antiprogestins share similar mechanism of action when acting as anti-proliferative agents, and which are their downstream targets, need to be investigated to identify the genetic background of ovarian cancers required for susceptibility to growth inhibition by antiprogestins.

In summary, the results from the present work provide evidence suggesting that antiprogestins originally utilized for reproductive medicine can be repurposed or repositioned for another modality-of-use, their anti-ovarian cancer property, which involves their capacity to ablate the activity of the cell cycle regulatory protein $\mathrm{Cdk} 2$.

Acknowledgements This research was supported by award number K22CA121991 and ARRA Supplement K22CA121991-S1 from the National Cancer Institute, the National Institutes of Health (NIH). The authors would like to thank Mr. Nahuel Telleria for editing the manuscript.

Open Access This article is distributed under the terms of the Creative Commons Attribution Noncommercial License which permits any noncommercial use, distribution, and reproduction in any medium, provided the original author(s) and source are credited.

\section{References}

1. Spitz IM (2006) Progesterone receptor antagonists. Curr Opin Investig Drugs 7(10):882-890

2. Benagiano G, Bastianelli C, Farris M (2008) Selective progesterone receptor modulators 1: use during pregnancy. Expert Opin Pharmacother 9(14):2459-2472. doi:10.1517/14656566.9.14.2459

3. Benagiano G, Bastianelli C, Farris M (2008) Selective progesterone receptor modulators 2 : use in reproductive medicine. Expert Opin Pharmacother 9(14):2473-2485. doi:10.1517/ 14656566.9.14.2473

4. Moller C, Hoffmann J, Kirkland TA, Schwede W (2008) Investigational developments for the treatment of progesteronedependent diseases. Expert Opin Investig Drugs 17(4):469-479. doi:10.1517/13543784.17.4.469

5. Li D-Q, Wang Z-B, Bai J, Zhao J, Wang Y, Hu K, Du Y-H (2004) Effects of mifepristone on proliferation of human gastric adenocarcinoma cell line SGC-7901 in vitro. World J Gastroenterol 10 (18):2628-2631

6. Matsuda Y, Kawamoto K, Kiya K, Kurisu K, Sugiyama K, Uozumi T (1994) Antitumor effects of antiprogesterones on human meningioma cells in vitro and in vivo. J Neurosurg 80(3):527-534

7. Navo MA, Smith JA, Gaikwad A, Burke T, Brown J, Ramondetta LM (2008) In vitro evaluation of the growth inhibition and apoptosis effect of mifepristone (RU486) in human Ishikawa and HEC1A endometrial cancer cell lines. Cancer Chemother Pharmacol 62(3):483-489. doi:10.1007/s00280-007-0628-Z

8. El Etreby MF, Liang Y, Johnson MH, Lewis RW (2000) Antitumor activity of mifepristone in the human LNCaP, LNCaP-C4, and LNCaP-C4-2 prostate cancer models in nude mice. Prostate 42(2):99-106

9. Musgrove EA, Lee CS, Cornish AL, Swarbrick A, Sutherland RL (1997) Antiprogestin inhibition of cell cycle progression in T-47D 
breast cancer cells is accompanied by induction of the cyclindependent kinase inhibitor p21. Mol Endocrinol 11(1):54-66

10. El Etreby MF, Liang Y, Wrenn RW, Schoenlein PV (1998) Additive effect of mifepristone and tamoxifen on apoptotic pathways in MCF-7 human breast cancer cells. Breast Cancer Res Treat 51(2):149-168

11. Yokoyama Y, Shinohara A, Takahashi Y, Wan X, Takahashi S, Niwa K, Tamaya T (2000) Synergistic effects of danazol and mifepristone on the cytotoxicity of $\mathrm{UCN}-01$ in hormoneresponsive breast cancer cells. Anticancer Res 20(5A):3131-3135

12. Schoenlein PV, Hou M, Samaddar JS, Gaddy VT, Thangaraju M, Lewis J, Johnson M, Ganapathy V, Kallab A, Barrett JT (2007) Downregulation of retinoblastoma protein is involved in the enhanced cytotoxicity of 4-hydroxytamoxifen plus mifepristone combination therapy versus antiestrogen monotherapy of human breast cancer. Int J Oncol 31(3):643-655

13. Gaddy VT, Barrett JT, Delk JN, Kallab AM, Porter AG, Schoenlein PV (2004) Mifepristone induces growth arrest, caspase activation, and apoptosis of estrogen receptorexpressing, antiestrogen-resistant breast cancer cells. Clin Cancer Res 10(15):5215-5225

14. Liang Y, Hou M, Kallab AM, Barrett JT, El Etreby F, Schoenlein PV (2003) Induction of antiproliferation and apoptosis in estrogen receptor negative MDA-231 human breast cancer cells by mifepristone and 4-hydroxytamoxifen combination therapy: a role for TGFbeta1. Int J Oncol 23(2):369-380

15. Poole AJ, Li Y, Kim Y, Lin SC, Lee WH, Lee EY (2006) Prevention of Brcal-mediated mammary tumorigenesis in mice by a progesterone antagonist. Science 314(5804):1467-1470. doi:10.1126/science.1130471

16. Jurado R, Lopez-Flores A, Alvarez A, Garcia-Lopez P (2009) Cisplatin cytotoxicity is increased by mifepristone in cervical carcinoma: an in vitro and in vivo study. Oncol Rep 22(5):1237-1245

17. Rose FV, Barnea ER (1996) Response of human ovarian carcinoma cell lines to antiprogestin mifepristone. Oncogene 12 (5):999-1003

18. Goyeneche AA, Caron RW, Telleria CM (2007) Mifepristone inhibits ovarian cancer cell growth in vitro and in vivo. Clin Cancer Res 13(11):3370-3379

19. Freeburg EM, Goyeneche AA, Seidel EE, Telleria CM (2009) Resistance to cisplatin does not affect sensitivity of human ovarian cancer cell lines to mifepristone cytotoxicity. Cancer Cell Int 9:4. doi:10.1186/1475-2867-9-4

20. Freeburg EM, Goyeneche AA, Telleria CM (2009) Mifepristone abrogates repopulation of ovarian cancer cells in between courses of cisplatin treatment. Int J Oncol 34(3):743-755

21. Belanger A, Philibert D, Teutsch G (1981) Regio and stereospecific synthesis of 11 beta-substituted 19-norsteroids. Influence of 11 beta-substitution on progesterone receptor affinity - (1). Steroids 37(4):361-382. doi:0039-128X(81)90039-8

22. Kloosterboer HJ, Deckers GH, Schoonen WG, Hanssen RG, Rose UM, Verbost PM, Hsiu JG, Williams RF, Hodgen GD (2000) Preclinical experience with two selective progesterone receptor modulators on breast and endometrium. Steroids 65(10-11):733740. doi:10.1016/S0039-128X(00)001896-6

23. Wiehle RD, Christov K, Mehta R (2007) Anti-progestins suppress the growth of established tumors induced by 7,12-dimethylbenz(a) anthracene: comparison between RU486 and a new 21substituted-19-nor-progestin. Oncol Rep 18(1):167-174

24. Xu Q, Takekida S, Ohara N, Chen W, Sitruk-Ware R, Johansson ED, Maruo T (2005) Progesterone receptor modulator CDB-2914 down-regulates proliferative cell nuclear antigen and $\mathrm{Bcl}-2$ protein expression and up-regulates caspase-3 and poly(adenosine 5'diphosphate-ribose) polymerase expression in cultured human uterine leiomyoma cells. J Clin Endocrinol Metab 90(2):953-961. doi:10.1210/jc.2004-1569
25. Levens ED, Potlog-Nahari C, Armstrong AY, Wesley R, Premkumar A, Blithe DL, Blocker W, Nieman LK (2008) CDB-2914 for uterine leiomyomata treatment: a randomized controlled trial. Obstet Gynecol 111(5):1129-1136. doi:10.1097/AOG.0b013e3181705d0e

26. Svensson EC, Markstrom E, Shao R, Andersson M, Billig H (2001) Progesterone receptor antagonists Org 31710 and RU 486 increase apoptosis in human periovulatory granulosa cells. Fertil Steril 76(6):1225-1231. doi:S0015-0282(01)02891-6

27. Fraser M, Leung BM, Yan X, Dan HC, Cheng JQ, Tsang BK (2003) p53 is a determinant of $\mathrm{X}$-linked inhibitor of apoptosis protein/Akt-mediated chemoresistance in human ovarian cancer cells. Cancer Res 63(21):7081-7088

28. Yaginuma Y, Westphal H (1992) Abnormal structure and expression of the p53 gene in human ovarian carcinoma cell lines. Cancer Res 52(15):4196-4199

29. Conradie R, Bruggeman FJ, Ciliberto A, Csikasz-Nagy A, Novak B, Westerhoff HV, Snoep JL (2010) Restriction point control of the mammalian cell cycle via the cyclin E/Cdk2:p27 complex. FEBS J 277(2):357-367. doi:10.1111/j.1742-4658.2009.07473.x

30. Yang ES, Burnstein KL (2003) Vitamin D inhibits G1 to S progression in $\mathrm{LNCaP}$ prostate cancer cells through p27Kip1 stabilization and Cdk2 mislocalization to the cytoplasm. J Biol Chem 278(47):46862-46868. doi:10.1074/jbc.M306340200

31. Brown KA, Roberts RL, Arteaga CL, Law BK (2004) Transforming growth factor-beta induces $\mathrm{Cdk} 2$ relocalization to the cytoplasm coincident with dephosphorylation of retinoblastoma tumor suppressor protein. Breast Cancer Res 6(2):R130-139. doi: $10.1186 /$ bcr762

32. Jemal A, Siegel R, Ward E, Murray T, Xu J, Smigal C, Thun MJ (2006) Cancer statistics, 2006. CA Cancer J Clin 56(2):106-130. doi:56/2/106

33. Guarneri V, Piacentini F, Barbieri E, Conte PF (2010) Achievements and unmet needs in the management of advanced ovarian cancer. Gynecol Oncol 117(2):152-158. doi:10.1016/j.ygyno.2009.11.033

34. Zhao J, Kennedy BK, Lawrence BD, Barbie DA, Matera AG, Fletcher JA, Harlow E (2000) NPAT links cyclin E-Cdk2 to the regulation of replication-dependent histone gene transcription. Genes Dev 14(18):2283-2297

35. Lents NH, Keenan SM, Bellone C, Baldassare JJ (2002) Stimulation of the Raf/MEK/ERK cascade is necessary and sufficient for activation and Thr-160 phosphorylation of a nuclear-targeted CDK2. J Biol Chem 277(49):47469-47475. doi:10.1074/jbc.M207425200

36. Flores O, Wang Z, Knudsen KE, Burnstein KL (2010) Nuclear targeting of cyclin-dependent kinase 2 reveals essential roles of cyclin-dependent kinase 2 localization and cyclin $\mathrm{E}$ in vitamin D-mediated growth inhibition. Endocrinology 151(3):896-908. doi:10.1210/en.2009-1116

37. Sui L, Dong Y, Ohno M, Sugimoto K, Tai Y, Hando T, Tokuda M (2001) Implication of malignancy and prognosis of p27(kip1), Cyclin E, and Cdk2 expression in epithelial ovarian tumors. Gynecol Oncol 83(1):56-63

38. Rosen DG, Yang G, Cai KQ, Bast RC Jr, Gershenson DM, Silva EG, Liu J (2005) Subcellular localization of p27kip1 expression predicts poor prognosis in human ovarian cancer. Clin Cancer Res 11(2 Pt 1):632-637. doi:11/2/632

39. Singer JD, Gurian-West M, Clurman B, Roberts JM (1999) Cullin-3 targets cyclin E for ubiquitination and controls $\mathrm{S}$ phase in mammalian cells. Genes Dev 13(18):2375-2387

40. Pajalunga D, Crescenzi M (2004) Regulation of cyclin E protein levels through E2F-mediated inhibition of degradation. Cell cycle (Georgetown Tex) 3(12):1572-1578. doi:1279

41. Freemantle SJ, Liu X, Feng Q, Galimberti F, Blumen S, Sekula D, Kitareewan S, Dragnev KH, Dmitrovsky E (2007) Cyclin degradation for cancer therapy and chemoprevention. J Cell Biochem 102(4):869-877. doi:10.1002/jcb.21519 
42. Tsvetkov LM, Yeh KH, Lee SJ, Sun H, Zhang H (1999) p27 (Kip1) ubiquitination and degradation is regulated by the SCF (Skp2) complex through phosphorylated Thr187 in p27. Curr Biol 9(12):661-664. doi:S0960-9822(99)80290-5

43. Bornstein G, Bloom J, Sitry-Shevah D, Nakayama K, Pagano M, Hershko A (2003) Role of the SCFSkp2 ubiquitin ligase in the degradation of p21Cip1 in S phase. J Biol Chem 278(28):2575225757. doi:10.1074/jbc.M301774200

44. Bazzaro M, Lee MK, Zoso A, Stirling WL, Santillan A, Shih Ie M, Roden RB (2006) Ubiquitin-proteasome system stress sensitizes ovarian cancer to proteasome inhibitor-induced apoptosis. Cancer Res 66(7):3754-3763. doi:10.1158/0008-5472.CAN-05-2321

45. Huang H, Regan KM, Lou Z, Chen J, Tindall DJ (2006) CDK2dependent phosphorylation of FOXO1 as an apoptotic response to DNA damage. Science 314(5797):294-297. doi:10.1126/ science. 1130512

46. Deans AJ, Khanna KK, McNees CJ, Mercurio C, Heierhorst J, McArthur GA (2006) Cyclin-dependent kinase 2 functions in normal DNA repair and is a therapeutic target in BRCA1-deficient cancers. Cancer Res 66(16):8219-8226. doi:10.1158/0008-5472.CAN-05-3945

47. Huang H, Tindall DJ (2007) CDK2 and FOXO1: a fork in the road for cell fate decisions. Cell cycle (Georgetown Tex) 6(8):902-906. doi:4122
48. Liang Y, Eid MA, El Etreby F, Lewis RW, Kumar MV (2002) Mifepristone-induced secretion of transforming growth factor beta1-induced apoptosis in prostate cancer cells. Int J Oncol 21 (6):1259-1267

49. Kamradt MC, Mohideen N, Vaughan AT (2000) RU486 increases radiosensitivity and restores apoptosis through modulation of HPV E6/E7 in dexamethasone-treated cervical carcinoma cells. Gynecol Oncol 77(1):177-182. doi:10.1006/ gyno.1999.5724

50. Bardon S, Vignon F, Montcourrier P, Rochefort H (1987) Steroid receptor-mediated cytotoxicity of an antiestrogen and an antiprogestin in breast cancer cells. Cancer Res 47(5):14411448

51. Zhou H, Luo MP, Schonthal AH, Pike MC, Stallcup MR, Blumenthal M, Zheng W, Dubeau L (2002) Effect of reproductive hormones on ovarian epithelial tumors: I. Effect on cell cycle activity. Cancer Biol Ther 1(3):300-306. doi:10230130

52. Blumenthal M, Kardosh A, Dubeau L, Borok Z, Schonthal AH (2003) Suppression of the transformed phenotype and induction of differentiation-like characteristics in cultured ovarian tumor cells by chronic treatment with progesterone. Mol Carcinog 38(4):160 169. doi: $10.1002 / \mathrm{mc} .10155$ 